Maciej Szymaszek

Pontifical University of John Paul II in Kraków

\title{
Comments on the templon screens of the churches in Kefr Zeh and Arnas, located on the Tur 'Abdin plateau
}

The Tur 'Abdin plateau is located in the south-eastern part of Turkey, near the Syrian border. ${ }^{1}$ The northern and eastern end of this area is demarcated by the Tigris River. The cities of Mardin, Dara and Nisibis determine the western and southern edges of the plateau.

For the next 1,000 years after the conquest of Alexander the Great Tur 'Abdin was in the zone of the Roman-Greek and Persian influence. The inhabitants, representing a variety of cultures and religions, contributed to the development of the region as well as influenced the formation of the unique art style of northern Mesopotamia.

The European researchers' interest in the area of Tur 'Abdin began at the turn of the $19^{\text {th }}$ and the $20^{\text {th }}$ centuries. At that time a number of publications were issued: Albert Socin's article on the geography of Tur 'Abdin, ${ }^{2}$ Oswald Parry's book describing his stay in the monasteries in that area, ${ }^{3}$ and Henry Pognon's study of Semitic inscriptions on the plateau. ${ }^{4}$

In 1909 and 1911 the area of Tur 'Abdin was studied in detail by the English traveller Gertrude Bell who compiled lengthy written and photographic records. ${ }^{5}$

${ }^{1}$ The detailed geographical description of the plateau was included in: A. Socin, "Zur Geographie des Tur “Abdin,” Zeitschrift der Deutschen Morgenländischen Gesellschaft 35 (1881), pp. 237-269.

${ }^{2}$ See footnote 1.

${ }^{3}$ O. H. Parry, Six Months in a Syrian Monastery, Piscataway 2001.

${ }^{4} \mathrm{H}$. Pognon, Inscriptions Sémitiques de la Syrie, de la Mésopotamie et de la région de Mossoul, Paris 1907.

${ }^{5}$ The names used in this paper are derived from G. Bell's findings. A significant part of her research, including letters, diaries and photographs, is available on the web page Gertrude Bell Archive: http://www.gerty.ncl.ac.uk/. Due to the fact that the number of illustrations to be published 
Her pictures and descriptions are an invaluable source of information on the Christian architecture of the plateau because her research presents buildings and their furnishings that no longer exist. ${ }^{6}$ During her two visits to Tur 'Abdin, Bell drew plans of over 40 chapels, churches and monasteries. The plans were published in 1910, 1911 and 1913 in conjunction with accompanying illustrations. ${ }^{7}$

While describing the characteristics of the churches for that region Bell distinguished a group of around 20 churches. They represent the so-called 'parochial' type ${ }^{8}$ All of them possess a characteristic elongated nave on the east-western axis enclosed by a semi-circular apse as well as an entrance on the southern side of the church.

The Church of Mar Azizael in Kefr Zeh, dated 700, is an example of 'parochial' type. ${ }^{9}$ On the church plan and the photographs made by the researcher a templon screen is visible, separating the nave from the sanctuary. This structure has not been preserved and the only testimony to its existence comes from Bell's records. ${ }^{10}$

The templon screen in the Church of Mar Azizael in Kefr Zeh is comprised of two columns supporting a moulded architrave. The space between the columns and the sidewalls was filled with a bricked wall. In the northern side of the bricked wall two holes were made. ${ }^{11}$ The capitals of the columns at the entrance connecting the nave with the sanctuary were decorated with leaf motifs. ${ }^{12}$ The capitals, however, were easily distinguishable from each other. The northern one was a row of fleshy leaves with a smooth semi-circular rolled-out edge. The southern capital was decorated with two rows of Acanthus leaves with

in this paper is severely limited, the catalogue numbers of the photographs published on the web page will be provided. The author would like to thank Dr. Mark Jackson from Newcastle University for access to the high resolution photographs.

${ }^{6}$ G. Bell, M. Mango, The Churches and Monasteries of Tur 'Abdin, London 1982, p. I.

${ }^{7}$ G. Bell, The Churches and Monasteries of the Tur Abdin, [in:] Amida, ed. by M. van Berchem, J. Strzygowski, Heidelberg 1910, pp. 224-262; G. Bell, Amurath to Amurath, London 1911; G. Bell, "Churches and Monasteries of the Tur Abdin and Neighbouring District," Zeitschrift für Geschichte der Architektur 9 (1913), pp. 61-112. The full articles from 1910 and 1913 were annotated by M. Mango and published in 1982, see footnote 6.

${ }^{8}$ G. Bell, M. Mango, The Churches..., pp. VIII-IX.

${ }^{9}$ Ibid., pp. 13-17; 44-47; 120-121. A detailed bibliography concerning the Church of Mar Azizael in Kefr Zeh is mentioned on page 120 in the catalogue appended to this study. The translation of the Syriac inscriptions from the church in Kefr Zeh can be found in H. Pognon's article, Inscriptions Sémitiques de la Syrie, de la Mésopotamie et de la région de Mossoul, Paris 1907, pp. 91-94; also in A. Palmer, "A Corpus of Inscriptions from Tur "Abdin and Environs," Oriens Christianus 71 (1987), pp. 76-77.

${ }^{10}$ See footnote 5. The photographs from the church are available on the Gertrude Bell Archive web page. The photographs possess the following catalogue numbers: M_208, M_209 (both from 1909), R_208, R_209, R_212, R_213 (from 1911).

${ }^{11}$ See photograph R 209.

${ }^{12}$ See photographs R_-212 and R_213. 
clearly marked sharp edges. Both of them were adorned with a wreathed garland encompassing the columns below the corners of the capitals, typical for the region of Tur 'Abdin. An analogous motif of the garland may also be found in the late seventh century Church of the Virgin in Hah - a village located not far from Kefr Zeh. ${ }^{13}$

During her first visit to Tur 'Abdin Gertrude Bell came to the conclusion that the templon screen in the Church of Mar Azizael was constructed later than the building itself. ${ }^{14}$ Furthermore, she claimed that the sculptor who created the capitals of the columns at the entrance connecting the nave and the sanctuary based his work on the capital in the northern part of the apse. ${ }^{15}$ Two years later, Bell changed her viewpoint, though, claiming that the screen was erected at the same time as the church itself. ${ }^{16}$ When summarising her opinion she underlined the fact that the style of the decorations was the same despite the differences in the sculptures, and the discrepancies between the particular elements were deliberate. ${ }^{17}$

However, Bell's line of reasoning is not convincing because the decoration of the capitals and friezes in the apse is clearly distinct from the embellishments of the columns. It is also difficult to agree with the hypothesis that the differences in the sculptures were deliberate. The visible style dissimilarities support the claim that the screen was added later. ${ }^{18}$

In 1936 the Church of Mar Azizael underwent thorough restoration work. ${ }^{19}$ While the brick vault was being repaired the templon screen and bema were removed, both of which were photographed by Bell. ${ }^{20}$ The new structure dividing the nave and the sanctuary was called a gate in the Syriac founders' inscriptions. Its construction and ornamentation differs from those of the earlier screen. ${ }^{21}$ The only motif repeated on both monuments is the wreathed garland adorning the capitals at the entrance to the sanctuary.

${ }^{13}$ See photographs M_224, M_230. On the subject of Church of the Virgin see G. Bell, M. Mango, The Churches..., pp. 20-23; 54-58; 134-135.

${ }^{14}$ G. Bell, M. Mango, The Churches..., p.14.

${ }^{15}$ Ibid., p. 15.

${ }^{16}$ Ibid., p. 46. Bell also stipulates that the platform, on which the screen was erected, was $88 \mathrm{~cm}$ higher than the level of the nave.

${ }^{17}$ Ibid., p. 46.

${ }^{18}$ It is important to notice that the English researcher did not mention the screen in Kefr Zeh in her detailed diary and her letters dating back to that time. The writings are published on the web page specified in footnote 5 .

${ }^{19}$ G. Bell, M. Mango, The Churches..., p. 120. The destroyed elements and modernizations introduced in the church after G. Bell's visit in 1911 are enumerated in the catalogue.

${ }^{20}$ See photograph R_208.

${ }^{21}$ The photographs with the present screen in the Church of Mar Azizael in Kefr Zeh are available on the website: http://www.bethsuryoyo.com/HomelandPhotos/Turkey/Kfarze/index. html [25.10.2010]. 
Gertrude Bell's records also prove that a templon screen used to exist in the Church of Mar Kyriakos in Arnas. ${ }^{22}$ The layout of the building, the horseshoelike shape of the apse arch and the sculptor's decorations of the apse are clearly closely related to those present in the above-mentioned church in Kefr Zeh. The similarities make it possible to postulate that both churches were erected at the same time, i.e., around the year 700 .

The screen in Arnas was comprised of four columns supporting the architrave. ${ }^{23}$ The structure was constructed later than the building itself, which is confirmed by the Syriac founders' inscription mounted near one of the capitals. ${ }^{24}$

The capitals of the columns visible in the photographs are made of a row of semi-circular, rolled-out leaves. The styling of those elements is similar to the style of the northern capital in the church in Kefr Zeh. ${ }^{25}$

The architrave in Arnas was adorned with a geometric sculpture, and the frieze was divided into square sections inscribed with diamonds (Fig.1). In particular segments a cross sign was frequently depicted with a clearly marked point of intersection between the two arms (Fig.2). However, the individual sectors on the southern side of the screen were adorned either with circles arranged into a symmetric net or a six-armed star inscribed into a diamond with bent edges (Fig.3). Those ornaments did not possess analogous decorations in any other churches on the Tur 'Abdin plateau although the striped motif arrangement using a cross inscribed into a central figure appears in some earlier Syriac manuscripts.

The archivolts presented in the Rabbula's Gospels, dating back to 586, are adorned in a similar way as the frieze in Arnas. ${ }^{26}$ On fol. 4 r. the decoration of the arch is comprised of repeated crosses inscribed into diamonds. This motif is enclosed in a circle and multiplied along the whole length of the archivolt. ${ }^{27}$

A similar pattern of decoration is also visible on fol. $9 \mathrm{r} .{ }^{28}$ Here the sign of the cross is replaced with a centrally located point surrounded by tiny dots from four sides. The geometrised pattern of points inscribed into a diamond and the continuity of the motif are corresponding to the sections on the southern side of the architrave in Arnas. In that part of the screen the edges of the diamonds

${ }^{22}$ G. Bell, M. Mango, The Churches..., pp. 15-17; 47-50, 99. A detailed bibliography concerning the Church of Mar Kyriakos is available on page 99.

${ }^{23}$ See photographs M_197 (from 1909), R_203 (from 1911).

${ }^{24}$ Additional information is available in footnote 38 .

${ }^{25}$ See photographs M_197, M_198, R_203.

${ }^{26}$ See C. Cecchelli, G. Furlani, M. Salmi, The Rabbula Gospels, facsimile edition of the miniatures of the Syriac manuscript Plut. I, 56 in the Medicaean-Laurentian Library, Oltun 1959. The Rabbula Gospels were digitalised and available in an electronic version on the web page of Medicaean-Laurentian Library in Florence: http://teca.bmlonline.it/TecaViewer/index. jsp?RisIdr=TECA0000025956\&keyworks=Plut.01.56 [25.10.2010].

${ }^{27}$ Ibid., fol. 4a.

${ }^{28}$ Ibid., fol. 9b. 
are concave and their side line has similarities to the adornments in Rabbula's illuminated manuscript. ${ }^{29}$

In two sections on the northern side of the frieze in the Church of Mar Kyriakos, the cross was created as a negative where the convex triangles form the corners of the cross (Fig.4). The intersection of the arms was also underlined by a convex square. This type of ornament can be compared with a motif appearing on fol. $151 \mathrm{v}$. of a sixth century Syriac manuscript, catalogue number 14591, which is kept in the British Museum. ${ }^{30}$ In both instances the sign becomes visible due to the filling out of the corners of the enclosing figures. Both on the manuscript and on the frieze in Arnas, there is a dot at the intersection of the cross, which underscores the criss-crossing of the axes.

Additionally, the architrave in the Church of Mar Kyriakos was encompassed by two ornamental strips. The upper part was a row of sharp-ended semi-cylinders topped with a sphere sector. The lower edge was decorated with an ornament comprised of alternating two semi-circles, the edges of which touch one another at the top of the arches.

At the time of Bell's visit the southern side of the screen was already incomplete, which is clearly visible in the photographs from 1909 and $1911 .{ }^{31}$ It is possible that on the same side, at the level of the architrave, a fragment of the ornament, which had run below the frieze, was laid in. This part is corresponding in size, style and type of ornament to the part noticeable in the archival photographs. ${ }^{32}$

The motif of alternating semi-circles appears not only in the sculptures of the Church of the Saints Sergius and Bacchus in Hah but also in the Syriac illuminated manuscripts connected with the area of northern Mesopotamia. ${ }^{33}$ It can be found on fol. $10 \mathrm{v}$. in the above-mentioned Rabbula's Gospels ${ }^{34}$ as well as in the manuscripts originating in Mardin (fol. 3 v.) and Midyat (fol. 289 v.) on the plateau of Tur 'Abdin and dating to the first part of the $13^{\text {th }}$ century. ${ }^{35}$

Thus it is not possible to agree with Gertrude Bell's thesis, claiming that the ornamentation of the templon screen in the Church of Mar Kyriakos "belongs

${ }^{29}$ Highlighting the central points in the frieze adornment in Arnas is also analogous to an illuminated manuscript depicting the ornament of the archivolt on fol. $14 \mathrm{r}$. in the Rabbula's Gospels, see C. Cecchelli, G. Furlani, M. Salami, The Rabbula..., fol. 14a.

${ }^{30} \mathrm{~J}$. Leroy, Les manuscrits syriaques à peintures conservés dans les Bibliothèques d'Europe et d'Orient: contribution à l'ètude de l'iconographie des Eglises de langue syriaque, Paris 1964, pp. 114, 116, illustration 3.1 .

${ }^{31}$ See photographs M_197, R_203.

${ }^{32}$ This fragment can be seen in photograph M_198.

${ }^{33}$ Such an ornament appears on the frame of a stone slate inlaid into a narthex wall in the Church of the Saints Sergius and Bacchus in Hah, see T. Sinclar, Eastern Turkey: An architectural and archeological survey, vol. 3, London 1989, p. 245.

${ }^{34}$ C. Cecchelli, G. Furlani, M. Salmi, The Rabbula..., fol. $10 \mathrm{~b}$.

${ }^{35}$ J. Leroy, Les manuscrits..., pp. 102, 140. 
without doubt to a later period, and to a different artistic tradition." 36 The motifs appearing on the architrave can be found on numerous monuments connected with this area. Additionally, they used to function in the style of ornamentation between the $6^{\text {th }}$ and the $13^{\text {th }}$ centuries at the least.

In the photograph from 1909 there are two rectangular plates, which were inlaid between the columns on both sides of the entrance connecting the nave and the sanctuary. ${ }^{37}$ Unfortunately, the English researcher does not mention those elements and due to the lack of any other records it is not possible to analyse their style.

The stone plate set at the level of the capital on the southern side of the screen in the Church of Mar Kyriakos is considered to be one of the oldest Christian epitaphs written in the Syriac language. ${ }^{38}$ It has not survived till the present day. The only proof of its existence comes from the afore-mentioned article written by Pognon and from Bell's photographs.

Since Gertrude Bell's visit to Arnas in 1911 the church has undergone a thorough renovation and the interior of the church was completely refurbished. In 1939 the screen, described as having a geometric ornamentation, was removed. ${ }^{39}$ The new structure is similar in its construction and decoration to the screen found in the church in Kefr Zeh, which was erected in $1936 .{ }^{40}$ Both screens were probably created by the same workshop. This fact is confirmed by the analogies in the shape of the decorations using stylised floral motifs. ${ }^{41}$

It is not known what happened to the templon screen in the Church of Mar Kyriakos. The only element that can be related to that structure is some part of the arch of the beth slotha chapel erected in the churchyard of the said church. The archives show that there is a clearly missing element in the top part of the arch, which at a later date was replaced with a reused material adorned with sculptures. The replacement is comprised of two parts and its right-hand side is correspondent to the decorative strip supporting the architrave in the earlier screen. When comparing the photograph from 1911 with the modern ones, the

${ }^{36}$ G. Bell, M. Mango, The Churches..., p. 50.

${ }^{37}$ See photograph M_197.

${ }^{38}$ A. Palmer, A Corpus..., pp. 121-123; A. Palmer, Monk and mason on the Tigris frontier. The early history of Tur 'Abdin, Cambridge 1990, pp. 209-210. The inscription includes the information that qestroma was built in 760-761 AD, and the templon screen was its part. The founder was to be the priest Elias who served as the rector of the church in Arnas. In the further part of the inscription the date of the founder's death is mentioned as well as some information about Isaac the patriarch and Cyriacus the bishop, who were to hold their offices during Elias's lifetime. The Syriac inscriptions from the church in Arnas were translated in 1907 for the first time, see H. Pognon, Inscriptions Sémitiques..., pp. 95-100; the picture of the inscription inlaid near the screen can be found in chart 24, no. 52.

${ }^{39}$ G. Bell, M. Mango, The Churches..., p. 99.

${ }^{40}$ See footnote 19.

${ }^{41}$ The photographs with the present-day screen in the Church of Mar Kyriakos in Arnas are available at: http://www.bethsuryoyo.com/HomelandPhotos/Turkey/Urdnos/index.html [25.10.2010]. 
repetitive motif of alternating semi-circles, the ends of which touch at the tops of the arches, is clearly distinguishable. Thus it is quite possible that the part of decorative architrave was used as a substitute and inlaid into the arch after 1939.

The templon screens in Kefr Zeh and Arnas are the only examples of such structures on the plateau of Tur 'Abdin. Despite the high level of devastation, the templon screens have not been forgotten thanks to Gertrude Bell's records. The screens used to be an element of qestroma and they are good examples of continuity in Christian art created after the Arab conquest in 640. The high value of the screen in the Church of Mar Kyriakos in Arnas is also connected with the Syriac text, proving its founding. Together with the inscription from Amida stored in the Vatican Museums ${ }^{42}$ it is an example of the oldest epitaph from the area of northern Mesopotamia.

${ }^{42}$ See A. Palmer, Monk and mason..., pp. 208-209. 


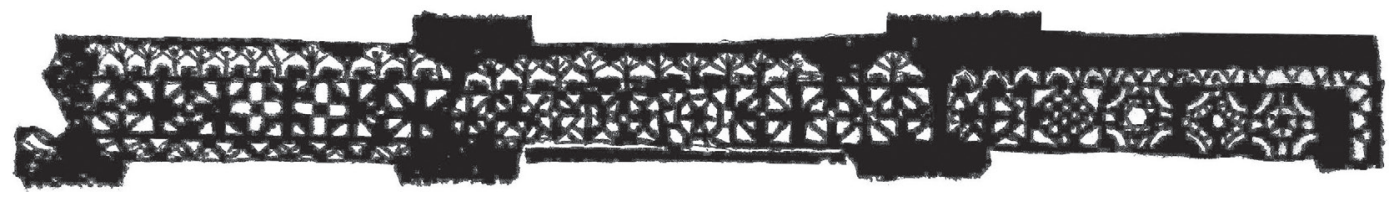

Figure 1

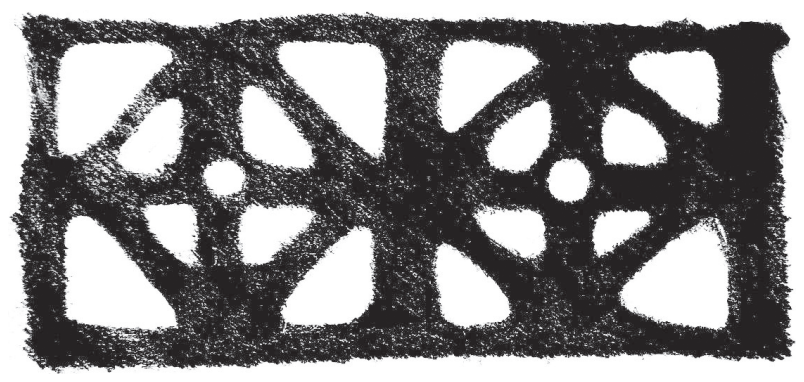

Figure 2

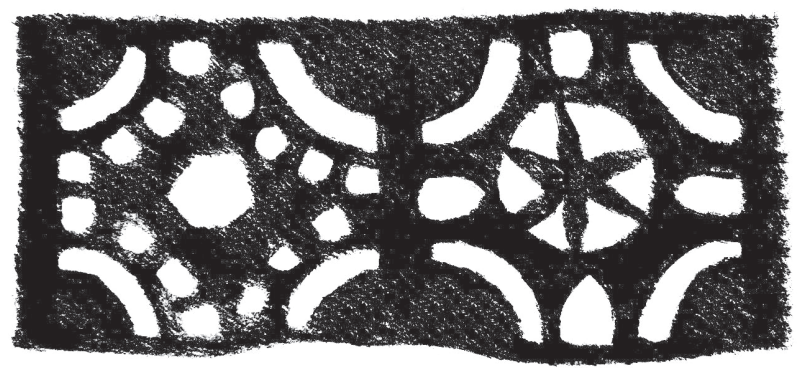

Figure 3

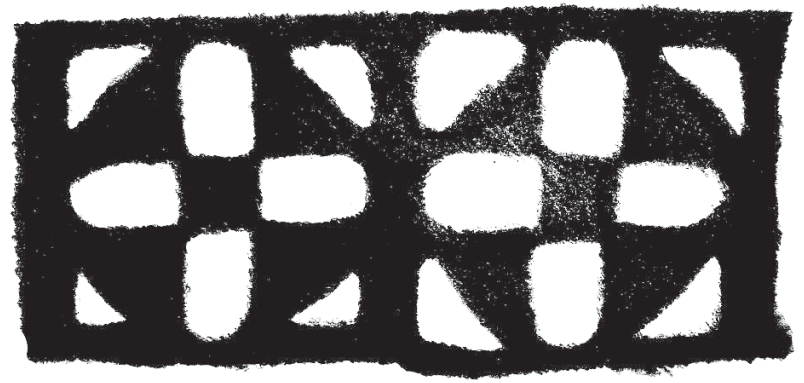

Figure 4 